\title{
THE EFFECT OF REVERSE FLOTATION METHOD ON SILICA SAND AS WATERPROOFING MORTAR
}

\author{
Okky Putri Prastuti ${ }^{1}$, Ayu Tri Septianingrum ${ }^{1}$, Elisya Dianty Fatmala ${ }^{1}$, \\ Ufafa Anggarini ${ }^{1}$, Tri Eddy Susanto ${ }^{2}$, Nuvixca Dewi Milangsari ${ }^{1}$ \\ ${ }^{1}$ Universitas Internasional Semen Indonesia, Jl. Veteran, Gresik, 61122 \\ ${ }^{2}$ PT.Semen Indonesia, Jl. Veteran, Gresik, 61122 \\ E-mail: okky.prastuti@uisi.ac.id
}

Received: 15 July 2020

Revised: 14 October 2020

Accepted: 21 October 2020

\begin{abstract}
THE EFFECT OFREVERSE FLOTATIONMETHOD ON SILICASANDAS WATERPROOFING MORTAR. Waterproof fabrication mortar cement by silica sand using reverse flotation silica (RFS) method was evaluated by waterproof absorption coefficient, compressive strength test, attractive test, and contact angle. RFS is used to replace waterproof agent and aggregate mortar to reduce cost. The aims of this experiment are to know RFS process, ratio between waterproof mortar cement with RFS and mortar, to determine performance and characteristic waterproof mortar cement. Methods used are prepare RFS, mortar cement fabrication, and testing (compressive strength, tensile strength, permeability, contact angle, XRF, FTIR, SEM, BET). Variable used are ratio cement/silica sand, concentrations of $\mathrm{CaCl}_{2}$, curing time, oleic acid and sodium oleate addition. Optimum collector addition is obtained by oleic acid with compress strength $167.65 \mathrm{~kg} / \mathrm{cm}^{2}$, tensile strength $0.16 \mathrm{MPa}$, permeability $4.6 \mathrm{~cm}$, and contact angle $95^{\circ}$. Curing inside water effect and outside temperature give compress strength $167.65 \mathrm{~kg} / \mathrm{cm}^{2}$ and $163.24 \mathrm{~kg} / \mathrm{cm}^{2}$, permeability curing inside water and outside temperature are $4.6 \mathrm{~cm}$ and $12 \mathrm{~cm}$. Optimum $\mathrm{CaCl}_{2}$ addition is gained at $\mathrm{CaCl}_{2} 1.8 \mathrm{M}$ with compress strength $64.29 \mathrm{~kg} /$ $\mathrm{cm}^{2}$, tensile strength $0.15 \mathrm{MPa}$, permeability $2.4 \mathrm{~cm}$, contact angle $95^{\circ}$. Optimum ratio cement/RFS is $1: 1$ with compress strength $167.65 \mathrm{~kg} / \mathrm{cm}^{2}$, tensile strength $0.16 \mathrm{MPa}$, permeability $4.6 \mathrm{~cm}$, and contact angle $95^{\circ}$.
\end{abstract}

Keywords: Mortar, Reverse flotation, Silica sand, Tailings, Waterproof

\begin{abstract}
ABSTRAK
PEMANFAATAN PASIRSILIKAPT.SEMENINDONESIASEBAGAIMOTAR WATERPROOF DENGAN PROSES REVERSE FLOTATION. Fabrikasi waterproof berbasis semen mortar dengan bahan baku pasir silika menggunakan metode reverse flotation silica (RFS) dievaluasi dengan koefisien penyerapan tahan air, kekuatan tekan, daya tarik dan sudut kontak. RFS digunakan untuk menggantikan sifat waterproof dan agregat mortar untuk mengurangi biaya. Tujuan dari penelitian ini adalah mengetahui proses RFS, mengetahui perbandingan mortar waterproof berbasis semen dengan RFS dan mortar, mengetahui kinerja dan karakteristik waterproof mortar RFS. Metode yang digunakan adalah persiapan RFS, fabrikasi mortar semen, dan pengukuran (kuat tekan, kuat tarik, permeabilitas, sudut kontak, XRF, FTIR, SEM, BET). Variabel yang digunakan adalah perbandingan semen/pasir silika, konsentrasi $\mathrm{CaCl}_{2}$, waktu curing, penambahan asam oleat dan sodium oleat. Penambahan kolektor paling optimal adalah asam oleat dengan kuat tekan sebesar $167,65 \mathrm{~kg} / \mathrm{cm}^{2}$, kuat tarik sebesar $0,16 \mathrm{MPa}$, permeabilitas 4,6 cm dan sudut kontak $95^{\circ}$. Pengaruh curing dalam air memiliki kuat tekan 167,65 kg/ $\mathrm{cm}^{2}$, curing suhu luar sebesar $163,24 \mathrm{~kg} / \mathrm{cm}^{2}$, permeabilitas curing dalam air sebesar $4,6 \mathrm{~cm}$, sedangkan
\end{abstract}


curing suhu luar $12 \mathrm{~cm}$. Penambahan $\mathrm{CaCl}_{2}$ yang optimum pada konsentrasi $\mathrm{CaCl}_{2} 1,8 \mathrm{M}$ pada uji kuat tekan sebesar $64,29 \mathrm{~kg} / \mathrm{cm}^{2}$, kuat tarik sebesar 0,15 MPa, permeabilitas sebesar 2,4 cm, sudut kontak sebesar $95^{\circ}$. Perbandingan semen/RFS optimal adalah 1:1 dengan kuat tekan sebesar $167,65 \mathrm{~kg} / \mathrm{cm}^{2}$, kuat tarik sebesar 0,16 MPa, permeabilitas sebesar 4,6 cm dan sudut kontak sebesar $95^{\circ}$.

Kata kunci: Mortar, Pasir silika, Reverse flotation, Tailing, Waterproof

\section{INTRODUCTION}

PT. Semen Indonesia (Persero) is a cement industry which use raw materials such as limestone and clay, beside that also need some corrective materials are silica sand, iron sand, cast stone, and trass. There are many kind tailing materials that produced by cement industry, silica sand is one of them. Silica sand contains $\mathrm{SiO}_{2}, \mathrm{FeO}$, $\mathrm{Al}_{2} \mathrm{O}_{3}, \mathrm{CaO}$, and $\mathrm{MgO}$. The greatest composition on silica sand is $\mathrm{SiO}_{2} 96.62 \%$, $\mathrm{FeO} 1.02 \%, \mathrm{Al}_{2} \mathrm{O}_{3} 1.54 \%, \mathrm{CaO} 0.57 \%$, and $\mathrm{MgO} 0.57 \%$ [1]. In this study, silica sand will be used as the main raw material for making waterproof mortar using the reverse flotation method. Flotation is the process of separating minerals and impurities. Collector material is required in this process, because it has a selective surface that is less due to its hydrophobic and hydrophilic groups. One of the chemicals that can be used as a collector is a surfactant [2], such as sodium oleic and oleic acid. The mechanism in the flotation process is to separate the impurities from silica sand. Based on Wang (2017) [3] reverse flotation silica is used to replace water repellent and aggregates in mortar so as to reduce fabrication costs.

In the previous research [3] entitled "Fabrication and mechanism of cement-based waterproof material using silicate tailings from reverse flotation" states that Reverse Flotation Silica (RFS) is able to absorb lower water than ordinary mortars. Meanwhile, both the internal and surface of the RFS mortar are hydrophobic, which exhibits waterproof characteristics. In this study, it is necessary to carry out further research on the use of $\mathrm{SiO}_{2}$ material from silica sand which can withstand water using the reverse flotation method. With the RFS / Cement comparison, we can find out the results of the optimum silica ratio for waterproof capability that can be applied in Indonesia and consider the curing method in order to produce better compressive strength and tensile strength than ordinary mortars.

According with the background discussed previously, the provisional hypothesis of this study is that the concentration of the collector used will have an effect on the amount of silica separated from its impurities. Besides that, the curing process and the concentration ratio will also affect the characterization results of the compressive strength test, flexural strength test, and permeability. The construction of a building, house, or facility that requires special performance for the water stage can use waterproof mortar products.

Most of the walls of a house or building show signs of humidity when exposed to heavy rainfall. The innovation of waterproof mortar products, it has advantage in reducing the humidity that occurs on the walls. This is because when using waterproof mortar, water cannot penetrate the walls. Besides that, it has good adhesion performance and when applied the mortar dries quickly.

\section{EXPERIMENTAL METHOD}

\section{Materials and Instruments}

Materials used on this experiment are $\mathrm{NaOH}$, oleic acid, sodium oleate, $\mathrm{CaCl}_{2}$ as activator, silica sand obtained form PT.Semen Indonesia. Product then characterized using XRF, FTIR, compressive strength test, tensile strength, permeability test, contact angle, SEM, and SAA. This research was conducted in cement research center laboratory of PT. Semen Indonesia.

\section{Method and Procedure}

In this experiment, reverse flotation method was used to separate $\mathrm{SiO}_{2}$ and impurities on silica sand. Silica sand was characterized using XRF (X-Ray Fluorescence Spectrometer) to know its composition. At reverse flotation, silica sand will be interacting with collector, in this experiment using sodium oleate. Sodium oleate was made by react oleic acid and $\mathrm{NaOH}$. Mortar was made using ratio between cement and RFS to know its characteristic. Ratio cement and RFS were used 1:1, 1:2, and 1:3. For curing condition using 2 kind types, inside water curing and outside water curing. This cement then tested using compressive strength, tensile strength, permeability, and contact angle. Permeability is the ease of concrete for water to pass through. Permeability testing conducting based on SNI where water seeps into the concrete less than $5 \mathrm{~cm}[4]$. 
Table 1. Composition Silica Sand by XRF

\begin{tabular}{cc}
\hline Composition & Result (\%wt) \\
\hline $\mathrm{SiO}_{2}$ & 91,11 \\
$\mathrm{Al}_{2} \mathrm{O}_{3}$ & 3,58 \\
$\mathrm{CaO}$ & 0,8 \\
$\mathrm{MgO}$ & 0,61 \\
$\mathrm{~K}_{2} \mathrm{O}$ & 0,87 \\
$\mathrm{SO}_{3}$ & 0,01 \\
$\mathrm{P}_{2} \mathrm{O}_{5}$ & 3,02 \\
\hline
\end{tabular}

Mortar waterproof as a product then characterized by XRF (X-Ray Fluorescence Spectrometer) to find the composition which consist in mortar, FTIR (Fourier Transform InfraRed Spectroscopy) to ensure the bounding of each atom, compressive strength test, tensile strength, permeability test, contact angle, SEM (Scanning Electron Microscope) to capture the surface area of mortar, and SAA (Surface Area Analyzer) to calculate the surface area.

\section{RESULT AND DISCUSSION}

On reverse flotation, impurities will float at surface and leaving $\mathrm{SiO}_{2}$ at bottom. Before it, silica sand was characterized by XRF and the biggest composition was gained by $\mathrm{SiO}_{2} 91.11 \%$. The results are shown at Table 1 .

Oleic acid then reacted with $\mathrm{NaOH}$ to produce sodium oleate. Reaction that happens shown as equation (1).

$$
\mathrm{C}_{17} \mathrm{H}_{34} \mathrm{COOH}+\mathrm{NaOH} \text { à } \mathrm{C}_{17} \mathrm{H}_{34} \mathrm{COONa}+\mathrm{H}_{2} \mathrm{O}
$$

Then sodium oleate was characterized by FTIR (shown at Figure 1) and give result at peak 2953,72 $\mathrm{cm}^{-1}$ and $2917,42 \mathrm{~cm}^{-1}$ shown asymmetric stretching group ($\mathrm{CH}_{2}$ ), at peak $1559,23 \mathrm{~cm}^{-1}$ shown symmetric stretching group (-COO), and at $1459,43 \mathrm{~cm}^{-1}$ shown the function to bounding vibrate from $\left(-\mathrm{CH}_{2}\right)$.

Waterproof cement was made using collectors to know its mechanical effect and adsorb effect such as compressive strength, tensile strength, permeability, and

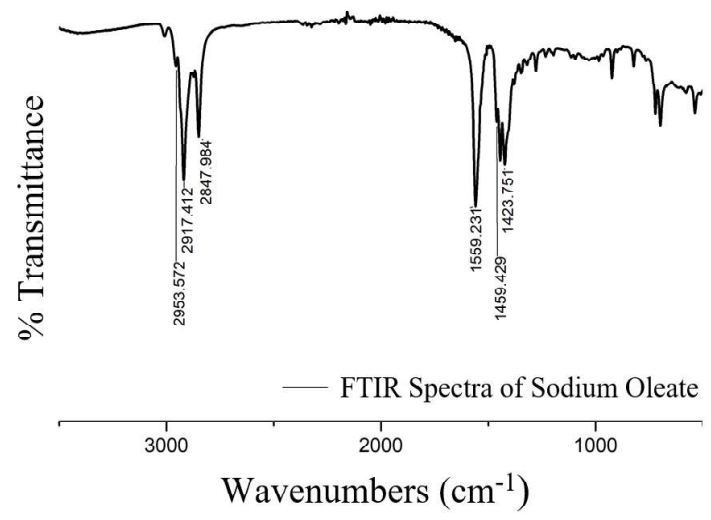

Figure 1. Sodium Oleate FTIR result

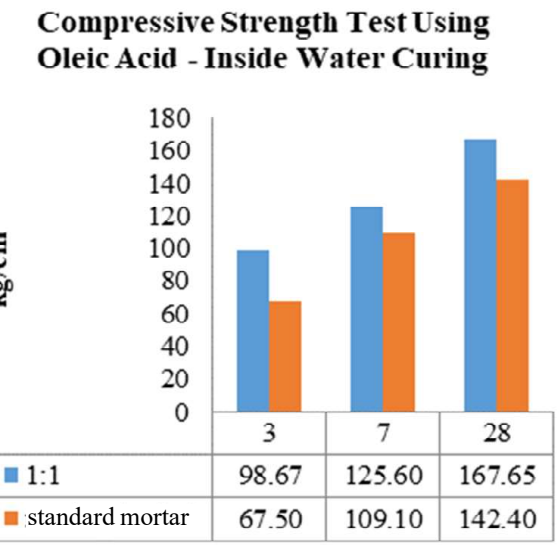

(a)

Compressive Strength Test Using Sodium Oleate - Inside Water Curing

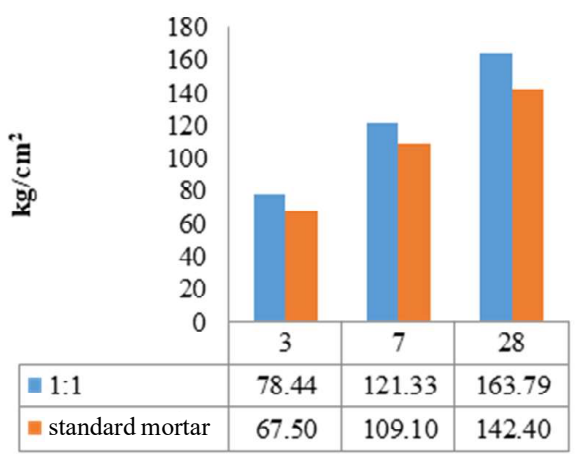

(b)

Figure 2. Compressive Strength Test Results Using (a) Oleic Acid and (b) Sodium Oleate as Collector

contact angle test. Collectors were used sodium oleate and oleic acid. For compressive strength test, sodium oleate and oleic acid was added to cement/RFS 1:1 and standard mortar. The results are shown Figure 2.

Based on Figure 2, collector oleic acid gives higher result than sodium oleate ( $2.3 \%$ higher). Based on Pastero (2017) sodium oleate is soap group that is not recommended for construction because it can cause mechanical damage and salinity (dissolved salt content in water) [5]. Whereas compressive strength value of oleic acid will decrease at a certain ratio. Acid content can damage the concrete should not exceed 15 gr/liter, because oleic acid release $\mathrm{H}^{+}$which causes corrosive when added to concrete, but the degree of corrosive $\mathrm{Na}^{+}$is higher than $\mathrm{H}^{+}[6]$. Besides that, acid content in the form of $\mathrm{H}^{+}$ions are free ions, when reacting with

Table 2. Tensile Strength Results Between Oleic Acid and Sodium Oleate Collector

\begin{tabular}{cc}
\hline Collector Variable & Tensile Strength (MPa) \\
\hline Olcic Acid $(1: 1)$ & 0,16 \\
Sodium Oleate $(1: 1)$ & 0,15 \\
Standard Mortar & 0,13 \\
\hline
\end{tabular}


Table 3. Permeability Results Between Oleic Acid and Sodium Oleate Collector

\begin{tabular}{ccc}
\hline Collcctor Variablc & Pcrmcability (cm) & Contact Anglc $\left(^{\circ}\right)$ \\
\hline Oleic Acid (1:1) & 4,6 & 95 \\
Sodium Oleate $(1: 1)$ & 4,7 & 95 \\
Standard Morlar & 8,1 & 85 \\
\hline
\end{tabular}

cement paste during hydration will reduce the bond between cement particles [6].

Tensile strength is an important characteristic that affects the propagation and size of structure cracks [7]. Based on Table 2, higher results gained by collector oleic acid. Both collectors have a bigger value than standard (0.003-0.1 MPa) [8]. Both of them got compressive strength value $15 \%$ higher than standard mortar. When the compressive strength using oleic acid collector increases, the value of the tensile strength using oleic acid collector will also increase, according to the SNI 6882-2014 standard. In this study using standard curing times, 3, 7, and 28 days. This is in accordance with national standard where the mortar is ready for use after a curing period of 28 days and is checked against the tensile strength value that is in accordance with the standard [8].

Permeability is the ease of concrete to be passed by water. Permeability testing of concrete based on SNI for watertight is required when water seeps into the concrete is less than $5 \mathrm{~cm}$ [4]. Table 3 shown that oleic acid and sodium oleate have lower permeability than standard mortar because oleic acid belongs to anionic collector group. Oleic acid and sodium oleate were used because they are belonging to unsaturated fatty acids, which better than saturated fatty acids, which more selective in reverse flotation process (RFS). Interaction between silica sand and collector will settle at bottom, while impurities will be bounding with bubble and rise to the surface to be separated [9]. While sodium oleate collector, can decrease the compressive strength value, and makes permeability value increases. It is caused by the addition of excess oleic salt will slow the hydration process of concrete, then cavities arise and cause the concrete to crack easily [10]. Based on Wahyuningtyas (2016) the addition of oleic acid as a lipid can decrease the tensile strength [11].

Contact angle is the angle formed between material surface and distilled water which is dripped onto the material surface. Based on the Table 3, oleic acid and sodium oleate gives contact angle highest than standard mortar. Contact angles more than $90^{\circ}$ are called hydrophobic (water repellent). Hydrophobic is useful for out-

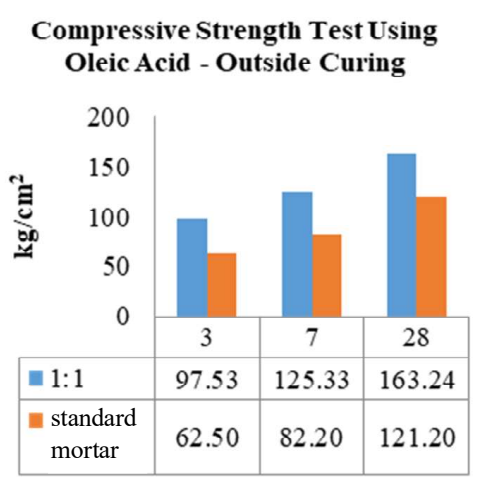

(a)

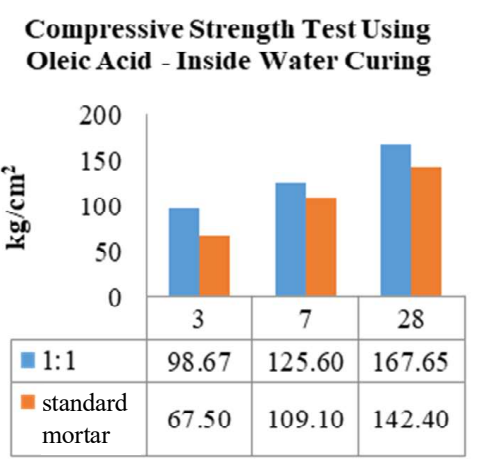

(b)

Figure 3. Compressive Strength Test Results Using Oleic Acid with (a) Outside Curing and (b) Inside Water Curing

door isolation because in wet or moist condition will not form a water layer [11].

Curing condition also gives some effect for waterproof cement. Curing is a concrete treatment when the concrete starts to crust. Curing aims to keep the concrete from losing water quickly and as an act of keep moisture or temperature of the concrete.

Based on Figure 3, compressive strength gives optimum value with inside water curing because due to curing in water, the lost water will be replaced by water around the immersed test specimen. Evaporation of mortar water will not occur quickly, because mortar will not lose the water needed for the hardening process [13] but the value of compressive strength at both conditions did not significantly different. Mortar maintenance process takes place regularly so as to avoid cracking the mortar and compressive strength of the mortar that is expected can be achieved and permeability value will be lower.

Table 4 shows outside curing permeability test more increased than inside curing condition because

Table 4. Permeability Results Between Inside and Outside Water Curing

\begin{tabular}{ccc}
\hline \multirow{2}{*}{ Collector Variable } & \multicolumn{2}{c}{ Permeability $(\mathbf{c m})$} \\
\cline { 2 - 3 } & Inside curing & Outside curing \\
\hline$\Lambda$ sam Oleat $(1: 1)$ & 4,6 & 12 \\
Mortar & 8,1 & 12 \\
\hline
\end{tabular}


Table 5. Addition Activator $\mathrm{CaCl} 2$ Effects for Mechanical and Adsorptivity Test

\begin{tabular}{cccc} 
Variable & $\mathbf{0 . 2 M}$ & $\mathbf{1 M}$ & $\mathbf{1 . 8 M}$ \\
\hline Compressive Strength $\left(\mathrm{kg} / \mathrm{cm}^{2}\right)$ & 53.24 & 57.33 & 64.29 \\
Tensile strength $(\mathrm{MPa})$ & 0.08 & 0.10 & 0.15 \\
Permeability $(\mathrm{cm})$ & 4.9 & 4.8 & 2.4 \\
Contact angle $\left({ }^{\circ}\right)$ & 90 & 92.5 & 95 \\
\hline
\end{tabular}

water can easily evaporate from mortar which caused by temperature or wind. The amount of evaporation of water will inhibit the cement hydration process. Hydration reaction is a reaction that occurs when cement is mixed with water. Based on [4] Oleic acid is an unsaturatedfatty-acids which is better than saturated fatty acids such as stearic and palmitic acid because it is more selective in repelling water. Meanwhile the standard for waterproof mortar which the permeability value should not be more than $5 \mathrm{~cm}$. The process of inside curing has fulfilled the requirement as a mortar waterproof than basic mortar and modified mortar with using outside curing as a treatment.

The effect of curing time on 28 days can produces higher compressive strength than curing time only 3 and 7 days. Mortar strength will increase while the permeability value decreases with age, whereas on 28 days, the mortar will gain greater strength [14]. Concrete compressive strength values may be various according to age and determined when concrete reaching the age of 28 days after production process. In general, when curing time 7 days, compressive strength test can achieve $70 \%$ and when curing time 14 days can achieve $85 \%-90 \%$ than curing time 28 days [ 15 ].

$\mathrm{CaCl}_{2}$ was used as activator on reverse flotation process. Activator that has functions as activation of metal ions which will be separated, so the flotation can perform maximally, through the exchange of ions. The variation in the concentration of the collector used was

Compressive Strength Using Oleic Acid - Curing Inside Water

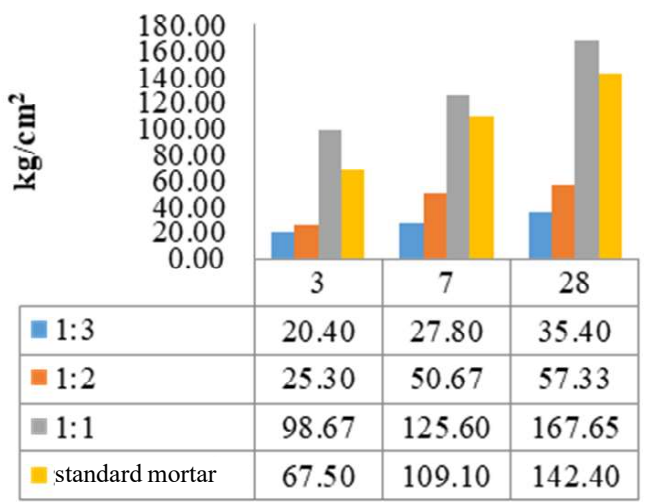

Figure 4. Compressive Strength Test Results With Addition of Cement/RFS and Standard Mortar adopted from previous research [3] which showed that oleic acid could be used as a collector of silica. Table 5 shows the greater addition of $\mathrm{CaCl}_{2}$ concentration, will gives better mechanical and absorptivity properties, because the flotation process will start quickly with the addition of $\mathrm{CaCl}_{2}$. Below is reaction of $\mathrm{CaCl}_{2}[16]$.

$$
\mathrm{CaCl}_{2} \rightarrow \mathrm{Ca}^{2+}+2 \mathrm{Cl}^{-}
$$

On reverse flotation, addition of oleic acid has functions to collect $\mathrm{SiO}_{2}$. Ion $\mathrm{Ca}^{2+}$ has functions to accelerate $\mathrm{SiO}_{2}$ binding in the reverse flotation process. The more $\mathrm{CaCl}_{2}$ will produced greater compressive strength and the more $\mathrm{Ca}^{2+}$ is released, the more $\mathrm{SiO}_{2}$ is collected. When $\mathrm{SiO}_{2}$ adheres to a large amount of oleic acid, then more $\mathrm{SiO}_{2}$ is added to the mortar and will increase durability of the mortar. Hydration process will walk slowly and prevent to form pores, then will produces mortar with a better mechanical property. The hydrophilic group of oleic acid can be adsorbed onto the surface of the silica mineral due to the presence of $\mathrm{Ca}^{2+}$ to form calcium oleate on the silica surface. The hydrophobic group of oleic acid forms a hydrophobic layer to prevent water molecules from absorbing onto the surface of silica minerals [17].

Figure 4 shows that ratio between cement/RFS $1: 1$ gained optimum results than ratio $1: 2,1: 3$, and standard mortar. Optimum results on ratio 1:1 caused by the same composition between cement and RFS so that gives maximum compressive strength value. This is corresponding to the highest compressive strength value at ratio aggregate/cement 3:5 and the lowest compressive strength at ratio 5:0 [18]. Mortar compressive strength increases with increasing levels of cement and decreases due to increased lime, sand, water [19].

Based on Table 6, optimum tensile strength achieved at ratio $1: 1$. This showed that the tensile strength value depends on the greater ratio of cement used and if the ratio of silica sand used is more, then the tensile strength will be smaller. Tensile strength results in ratio $1: 1,1: 2$, and 1:3 was appropriate with standard (0.003-0.1 MPa) [8].

From Table 6 the ratio between cement/RFS 1:1, $1: 2$, and $1: 3$ gives optimum result than standard mortar.

Table 6. Mechanical and Adsorptivity Result Using Cement/RFS in Various Ratio

\begin{tabular}{ccccc} 
Variable & $\mathbf{1 : 1}$ & $\mathbf{1 : 2}$ & $\mathbf{1 : 3}$ & Std. mortar \\
\hline Tensile strength $(\mathrm{MPa})$ & 0.16 & 0.10 & 0.08 & 0.13 \\
Permeability $(\mathrm{cm})$ & 4.6 & 4.8 & 4.9 & 8.1 \\
Contact $\Lambda$ ngle $\left({ }^{\circ}\right)$ & 95 & 92.5 & 92.5 & 85 \\
\hline
\end{tabular}




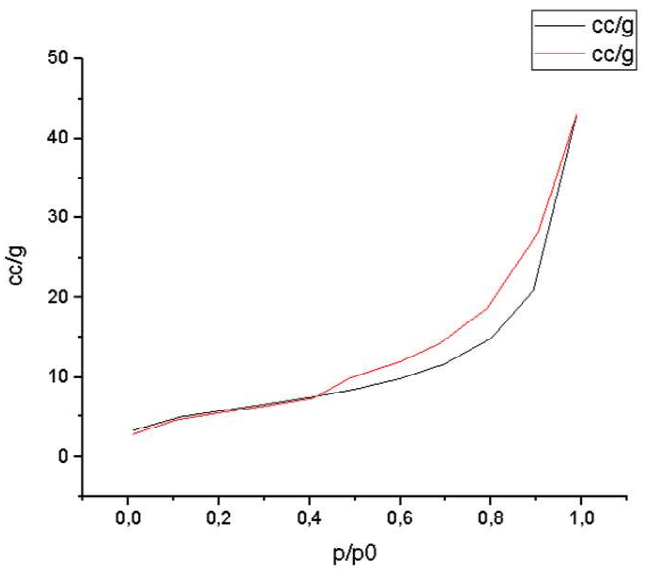

(a)

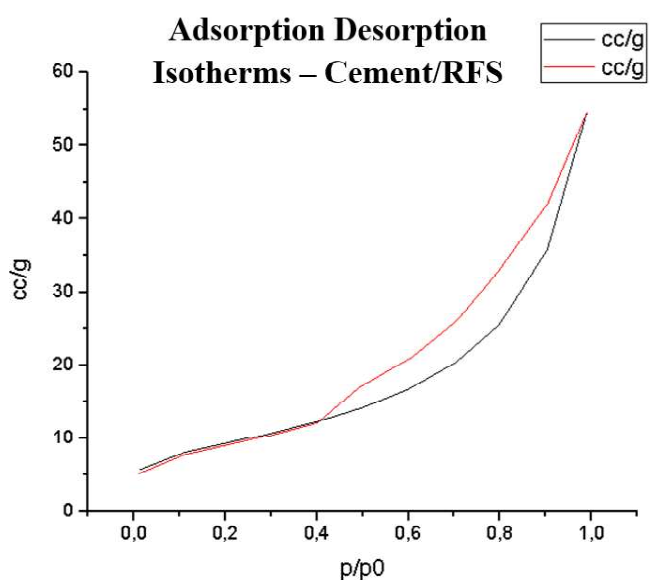

(b)

Figure 5. SAA Characterization Results of (a) Standard Mortar; (b) Cement/RFS 1:3

In ratio $1: 1$ has lower permeability than ratio $1: 2$ and $1: 3$. It is caused on the ratio 1:2 and 1:3 use silica sand more than cement, so can produce more pores on mortar. The more pores on mortar can caused water loss which causes shrinkage. Shrinkage that occurs can cause cracks in the mortar and the number of pores in the mortar can increase permeability [20]. The existence of shrinkage in concrete is caused by the loss of water too quickly.

Table 6 shows that in ratio 1:1, 1:2, and 1:3 gained optimum result than standard mortar. In ratio $1: 1$ has contact angle highest than ratio $1: 2$ and 1:3. Contact angles more than $90^{\circ}$ are called hydrophobic. Whereas usually outside temperatures and standard mortar, the contact angle is not in accordance with standard. So, when at outside temperature curing and standard mortar, it is not hydrophobic or partially wet [12].

In order to know further about characteristic of product, it is characterized using SAA (Surface Area Analyzer) and SEM (Scanning Electron Microscope). SAA characterization gives result as Figure 5.
Table 7. BET Results using SAA Characterization

\begin{tabular}{cccc}
\hline Variable & $\begin{array}{c}\text { Surface area } \\
\left(\mathbf{m}^{2} / \mathbf{g}\right)\end{array}$ & $\begin{array}{c}\text { Particle size } \\
(\mathbf{n m})\end{array}$ & $\begin{array}{c}\text { Pore size } \\
(\mathbf{n m})\end{array}$ \\
\hline Cement/RFS 1:3 & 20.2374 & 296.4807 & 13.1588 \\
Standard mortar & 33.1188 & 181.1662 & 10.1775 \\
\hline
\end{tabular}

From Figure 5 (a) and (b) know that isothermal adsorption graph of this mesoporous material has a characteristic hysteresis loop caused by capillary condensation in the mesoporous. When the pressure is decrease for gas adsorption, the isothermal curve shows a hysteresis loop where the amount of gas desorbed does not equal with the amount adsorbed gas at beginning. In other words, the amount of gas depleted is smaller than that of the depleted gas. It is caused by capillary condensation in the mesoporous [21]. Table 7 is BET result from SAA characterization.

According to Table 7, particles are classified mesoporous because its pore diameter more than $2 \mathrm{~nm}$ and less than $50 \mathrm{~nm}$. Porous structure is related to surface area where in standard mortar the smaller the pore size causing the greater surface area, so that the adsorption capacity will increases. This is inversely with cement/

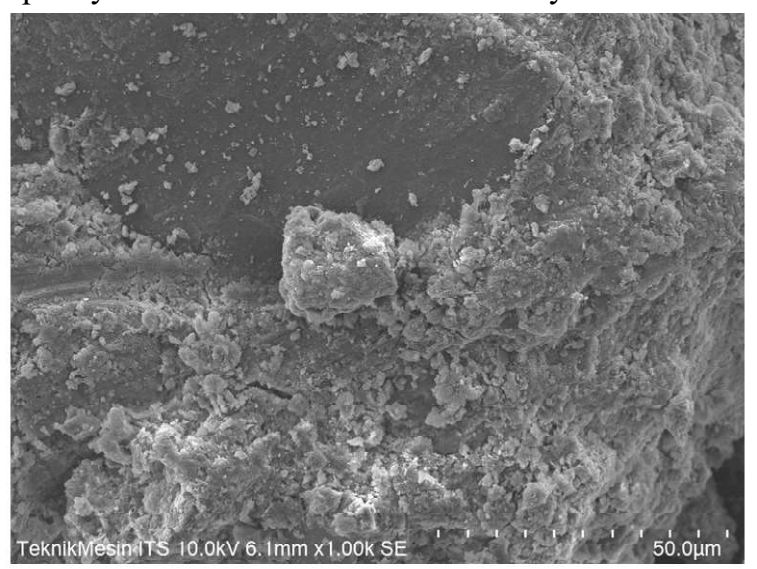

(a)

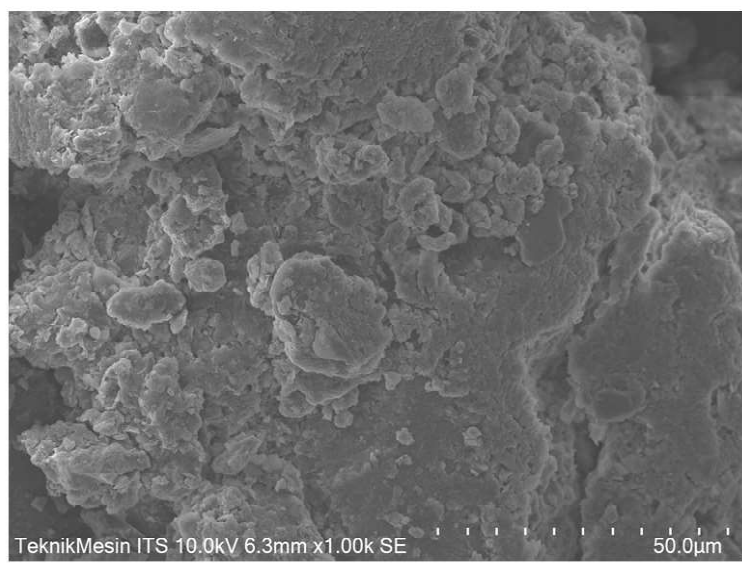

(b)

Figure 6. SEM Results (Magnification 1000x) of (a) Standard Mortar; (b) RFS Mortar 
RFS 1:3, where larger pore size of particles will cause smaller surface area, so adsorption ability will reduce waterproof [22].

Scanning Electron Microscope (SEM) is an electron microscope that is designed to observe the surface of a solid object. SEM has a magnification about $10-3,000,000$ times, depth of field $4-0.4 \mathrm{~mm}$ and a resolution of $1-10 \mathrm{~nm}$. From SEM characterization show that RFS mortars have a more compact structure than standard mortar. Besides that, according to Table 7 cement/RFS has smaller surface area than standard mortar. This shows that RFS mortars have a more compact structure compared to standard mortar, which can see at Figure 6.

\section{CONCLUSION}

On reverse flotation, silica sand which contain $\mathrm{SiO}_{2}$ is drown and impurities will float at surface. Oleic acid has optimal value with compressive strength $167.65 \mathrm{~kg} / \mathrm{cm}^{2}$, tensile strength $0.16 \mathrm{MPa}$, permeability 4.6 $\mathrm{cm}$ and contact angle $95^{\circ}$. Optimum ratio between cement/RFS as a mortar waterproof is $1: 1$ with compressive strength $167.65 \mathrm{~kg} / \mathrm{cm}^{2}$, tensile strength $0.16 \mathrm{MPa}$, permeability $4.6 \mathrm{~cm}$, and contact angle $95^{\circ}$.

\section{ACKNOWLEDGMENT}

Our acknowledgment is dedicated to research grant LPPM UISI which is funding this research.

\section{REFERSENCES}

[1] M. I. Narasimha and R. J. Babu. "Investigations on Physical and Chemical Properties of High Silica Sand, Fe-Cr Slag and Blast Furnace Slag for Foundry Applications." Journal Environmental Sciences, vol. 35, pp. 583-596, 2016.

[2] N. Idiawati, A. Triantie, and N. Wahyuni. "Pemisahan Timbal $\mathrm{Pb}$ dalam Galena dengan Metode Flotasi Menggunakan Deterjen.” Jurnal Progam Studi Kimia Universitas Tanjungpura. vol. 3, No. 1, pp. 01-05, 2013.

[3] W. Wang, Y.Zhao, H. Liu, and S. Song. "Fabrication and Mechanism of Cement Based Waterproof Material Using Silicate Tailings from Reverse Flotation." Journal Environmental Engineering. Vol.315, pp 422-429, 2017.

[4] M. D. Aulia. "Studi Eksperimental Permeabilitas dan Kuat Tekan Beton K-450 Menggunakan Zat Adiktif
Conplast WP421.” Jurnal Ilmiah UNIKOM. vol 10, no. 2, 2016

[5] L. Pastero, and D. Aquilano. "Calcium Carbonate Polymorphs Growing in the Presence of Sericin." Crystals MDPI Journal. vol 8, no. 7, pp. 263-270. 2017.

[6] R. S. W. Putri. "Pengaruh Abrasi Air Laut pada Beton dengan Bahan Tambah Berbasis Gula Ditinjau dari Berat Jenis, Kuat Tekan, dan Porositas". Thesis, Universitas Sebelas Maret, Indonesia, 2012.

[7] F. P. Pane. "Pengujian Kuat Tarik Lentur Beton Dengan Variasi Kuat Tekan Beton". Jurnal Sipil Statik. vol. 3, no. 5, pp. 313-321. 2015.

[8] SS-EN 1015-12. "Methods of test for mortar for masonry- Part 12: Determination of adhesive strength of hardened rendering and plastering mortars on substrates." Swedish Standard, pp. 111, 2016.

[9] E. G. Kelly and D. J. Spottiswood. Introduction to Mineral Processing. New York: Willey Interscience Publication. 1982.

[10] I. Firmansyah. "Penggunaan Kolektor Asam Oleik Dan Frother Minyak Pinus Pada Proses Flotasi Biji Nikel Limonit.” Thesis, Universitas Indonesia, Indonesia, 2009.

[11] M. Wahyuningtyas and L. Atmaja. "Pembuatan dan Karakterisasi Film Pati Kulit Are Singkong/ Kitosan dengan Plastisizer Asam Oleat." Jurnal Of Chemical Science. vol. 5, no. 1, pp 28-35, 2016.

[12] J. M. Illston and P.L.J. Domone. Construction Materials: Their Nature and Behavior $3^{\text {rd }} \mathrm{ed}$. London: Spon Press. 2001.

[13] A.T. Septianingrum and E. Dianty. "Penambahan polimer EVA/VEOVA pada Waterproof Cement Termodifikasi." Jurnal Teknik Kimia. vol. 14, no. 1, pp 10-15, 2019.

[14] Syakur, I. Novia, S. Sarjiya and H. Berahim. "Pengaruh Penambahan Silikon Terhadap Sudut Kontak Hidropobik Dan Karakteristik Arus Bocor Permukaan Bahan Resin Epoksi.” Jurnal Teknik, vol. 32, no. 3, pp 198-202, Feb. 2012.

[15] R. Y. Adi. "Kuat Tekan Mortar dengan Berbagai Campuran Penyusun dan Umur," Media Komunikasi Teknik Sipil, vol. 17, no. 1, pp. 67-84, Feb. 2012.

[16] R. Susanto. "Pengaruh cara perawatan terhadap kuat tekan dan kuat lentur beton berserat campuran 
(Baja dan Polypropylene)." Thesis, Universitas Negeri Yogyakarta, Indonesia, 2015.

[17] D. Amalia, M. Aziz, and Y. Yuhelda. "Pengaruh Penambahan Kalsium Klorida, Kalsium Hidroksida dan Karbon Aktif terhadap Penurunan Silika Terlarut dalam Larutan Sodium Aluminat.” Jurnal Teknologi Mineral Dan Batubara. vol. 9, no.3, pp. 157-164, 2013.

[18] H. Liu, W. Wang, Y. Zhao, and S. Song. "The Water Resistance of Cement Mortars Prepared with Reverse Flotation Tailings." Magazine of Concrete Research, vol. 69, no. 18, pp. 966-972, Sep. 2017.
[19] A. Ginting. "Kuat Tekan dan Porositas Beton Porous dengan Bahan Pengisi Styrofoam. "Jurnal Teknik Sipil. vol. 11, no. 2, pp. 76-168, 2015

[20] B. S. Nasional. "Specification for Mortar For Unit Masonrry." SNI 6882-2014. Jakarta, pp 1-48, 2014.

[21] S. Octaviani. "Sintesis Dan Karakterisasi Zeolit Zsm-5 Mesopori Dengan Metode Desilikasi Dan Studi Awal Katalisis Oksidasi Metana”, Thesis, Universitas Indonesia, Indonesia, 2012.

[22] I.S. Hardyanti, I. Nurani, D. S. Hardjono, E. Apriliani, and E. A. P. Wibowo. "Pemanfaatan Silika $\left(\mathrm{SiO}_{2}\right)$ dan Bentonit sebagai Adsorben Logam Berat Fe pada Limbah Batik." Jurnal Sains Terapan, vol. 3, no. 2, pp. 37-41, Oct. 2017. 